\section{Influence of Arbuscular Mycorrhizae Indigenous to Peru and a Flavonoid on Growth, Yield, and Leaf Elemental Concentration of 'Yungay' Potatoes}

Fred T. Davies, Jr. $^{1}$

Department of Horticultural Sciences, Texas A\&MUniversity, College Station, TX 77843-2133

Constantino M. Calderón ${ }^{2}$

Dpto. de Suelos, Facultad de Agronomia, Universidad Nacional Agraria La Molina (UNALM), Apdo. 456 La Molina, Lima 1, Peru

\section{Zosimo Huaman ${ }^{3}$ \\ International Potato Center, Lima, Peru}

Additional index words. arbuscular mycorrhiza, phosphorus use efficiency, nutrition, formononetin, endomycorrhiza, biofertilizers

\begin{abstract}
The influence of arbuscular mycorrhizal fungi (AMF) [two Peruvian mixed isolates, a pure isolate of Glomus intraradices] and the flavonoid, formononetin, were tested on growth, yield, and leaf elemental concentration of the Peruvian potato (Solanum tuberosum L.) 'Yungay'. Plants started from tissue culture-produced prenuclear minitubers of 'Yungay' were subjected to seven treatments, which included noncolonized (non-AMF) plants fertilized with Long Ashton nutrient solution modified to supply $P$ at 11 and $44 \mu \mathrm{g} \cdot \mathrm{mL}^{-1}$. All AMF plants received low $P\left(11 \mu \mathrm{g} \cdot \mathrm{mL}^{-1}\right)$ and were inoculated with either a sierra-maize mixed isolate, sierra-papa mixed isolate, pure isolate of $G$. intraradices, sierra-maize mixed isolate + formononetin, or a sierra-papa mixed isolate + formononetin. Plants were grown in 3-L containers under shade house conditions in Lima, Peru. Non-AMF plants at low $P$ had the poorest growth, while high $P$ plants had the greatest overall growth. All AMF plants had greater growth, including a higher root to shoot ratio, higher phosphorus use efficiency $[(\mathrm{g}$ tuber $) /(\mathrm{g} \mathrm{P} / \mathrm{kg}$ tissue) $]$, and a lower leaf to tuber ratio (indicating greater leaf efficiency in producing tuber dry matter), compared to non-AMF plants at low $P$. The mycorrhizal inoculation effect (MIE) ranged from $+\mathbf{4 4 \%}$ to $+\mathbf{5 7 \%}$, indicating that 'Yungay' was moderately to highly mycorrhizal dependent. Plants colonized with the sierra-papa isolate + formononetin had the same tuber development and leaf to tuber ratio, compared to high P, non-AMF plants. Formononetin increased extraradical hyphae formation. Mycorrhizal enhancement was in part due to greater $\mathrm{P}, \mathrm{Fe}$, and Mg uptake, a higher phosphorus-use efficiency and greater extraradical hyphae formation.
\end{abstract}

Potatoes (Solanum tuberosum L.) are grown worldwide under a wider range of altitude, latitude, and climatic conditions than any other major food crop-from sea level to $>4000 \mathrm{~m}$ elevation. No other crop can match the potato

in its production of food energy and food value per unit area (Sieczka and Thronton, 1992). It is also high in Vitamin C, niacin, and vitamin $\mathrm{B}_{6}$. Yet, the potato plant has one of the heaviest production demands for fertilizer inputs of all

\footnotetext{
Received for publication 15 May 2004. Accepted for publication 28 Sept. 2004. Use of trade names does not imply endorsement of named products nor criticism of similar ones not named. This research was supported in part by a J.S. Guggenheim Fellowship, Fulbright Senior Fellowship, and USDA-FAS grant \#58-3148-9052 to F.T.D. The technical assistance of Irene Chauca, Oscar Jorges, Lucho Quintanilla Rivera, Juan Guerrero Lázaro, Alexandra Davies-Lazarte and Katerina Davies-Lazarte was greatly appreciated. We thank Andres Estrada-Luna for critically reviewing the manuscript. We thank Julio Nazario, Laboratorio de Analysis de Suelos, Plantas, Aguas y Fertilizantes de UNALM, for conducting the soil analysis. We thank Alejandro Alarcon for some of the technical analysis of the mycorrhizal colonization. The authors wish to thank R. E. Schutzki for supplying the formononetin [Myconate, VAMTech L.L.C., Lansing, Mich.], A. M. Golmirzaie at the International Potato Center (CIP) for supplying the tissue-culture produced minitubers and Efrain Malpartida for supplying the Italian rye seed for trap cultures. We thank Neil Anderson, Reforestation Tech International (RTI) for supplying the Glomus intraradices, and Erasmo Marinez Espinoza and Constantina Calderón, indigenous Kechua farmers of Oyolo, Ayachucho, Peru, for assistance with the initial collection of AMF for multiplication. We thank Humberto A. Mendoza of the Potato Breeding Program at UNALM for use of the potato shade house.

1Professor. To whom reprint requests should be addressed; e-mail f-davies@tamu.edu.

2Professor; email cscam_5@hotmail.com.

${ }^{3}$ Former research scientist and geneticist. Currently international consultant; PROBIOANDES, Calle El Herraje No. 120, La Molina, Lima 12, PERU; email zosimohuaman@yahoo.com; http://www.geocities. $\mathrm{com} /$ probioandes/Pro Biodiversidad de los Andes.
}

vegetable crops, i.e., its $\mathrm{N}, \mathrm{P}$, and $\mathrm{K}$ requirements are respectively $100 \%, 100 \%$, and $33 \%$ greater than that required for tomato or pepper plant production (Maynard and Hochmuth, 1997). Normal fertilizer applications are around $1000 \mathrm{~kg} \cdot \mathrm{ha}^{-1}$ of $10-30-10(10 \mathrm{~N}-12.9 \mathrm{P}-8.3 \mathrm{~K})$. Subsistence growers may not have access or be able to afford suitable organic or inorganic fertilizers. Modern sustainable agriculture systems are increasingly using reduced fertility inputs. Hence, there are excellent opportunities to incorporate arbuscular mycorrhizal fungi (AMF) as biofertilizers to enhance crop productivity and reduce fertilizer inputs.

AMF increase nutrient and water uptake, alleviate cultural and environmental stresses and enhance disease resistance and plant health (Bethlenfalvay and Linderman, 1992; Davies, et al., 1993, 1996; Pfleger and Linderman, 1994). AMF can enhance productivity of potatoes (Graham et al., 1976; Niemira et al., 1995). In part this may be due to enhanced nutrient uptake of potato plants, particularly P (Black and Tinker, 1977; McArther and Knowles, 1993), as well as enhanced disease resistance (Niemira et al., 1996). In Columbia, experiments show that a considerable amount of $P$ fertilizer can be saved when potatoes are inoculated with effective AMF (Sieverding, 1991).

The highlands of Peru and Bolivia are the center of origin and diversity of the cultivated potato. Potato is the main staple crop in the highlands and accounts for $63 \%$ gross value of all crop production (Devaux et al., 1997). Average potato yields are very low (from 5 to 8 $\mathrm{t} \cdot \mathrm{ha}^{-1}$ ) and limited by low fertility. While small producers apply organic $\mathrm{N}$ as animal or green manure, $\mathrm{P}$ is applied via chemical fertilizers which are costly and not always available. For subsistence and modern sustainable potato production in Peru it is important that native AMF isolates be selected. A limitation of mycorrhiza utilization is its commercial availability and the added production cost.

The flavonoid, formononetin, has been reported to enhance mycorrhizal effectivity of mycorrhizal plants (Nair et al., 1997; Davies et al., 1999; Koide et al., 1999). Formononetin could be utilized with introduced AMF to permit lower, more cost-effective levels of AMF inocula, or applied to stimulate indigenous AMF. The objectives of this research were to evaluate Peruvian AMF isolates as biofertilizers that enhance potato crop yield of the important Peruvian cultivar 'Yungay', while reducing fertility inputs required. A second objective was to determine if nutrient uptake efficiency differs among selected AMF isolates, including phosphorus use efficiency (PUE). The effect of formononetin on stimulating native mycorrhizal inoculum was also determined. A long-term goal of this research is to utilize formononetin or other effective flavonoids in stimulating native populations of mycorrhiza to enhance potato crop productivity.

\section{Materials and Methods}

Cultural conditions. This study was conducted under shade house conditions at the Universidad Nacional Agraria La Molina 
(UNALM) in Lima, Peru. Tissue cultureproduced prenuclear minitubers (about 2.5 $\mathrm{cm}$ in diameter) of 'Yungay' potatoes were transplanted into 3.0-L pots containing 1 coarse sand: 1 low-P sandy loam soil (franco arenoso) $(\mathrm{v} / \mathrm{v})$ with a textural analysis of $75 \%$ sand, $8 \%$ clay and $17 \%$ silt. The soil medium had an EC of $0.51 \mathrm{dS} \cdot \mathrm{m}^{-1}, \mathrm{pH} 7.9,0.33 \% \mathrm{CaCO}_{3}, 1.2 \%$ $\mathrm{MO}, 5.8 \mu \mathrm{g} \cdot \mathrm{g}^{-1} \mathrm{P}$ and $299 \mathrm{~kg} \cdot \mathrm{ha}^{-1} \mathrm{~K}_{2} \mathrm{O}$. The medium was previously steam autoclaved at $110^{\circ} \mathrm{C}$. Pots were irrigated as needed and fertilized weekly after shoots emerged using 500 $\mathrm{mL}$ per pot of modified Long Ashton nutrient solution [LANS (Hewitt, 1966)] to supply P at 11 or $44 \mu \mathrm{g} \cdot \mathrm{mL}^{-1}$.

The 7 treatments were 1) noninoculated (non-AMF) at low $\mathrm{P}\left(11 \mu \mathrm{g} \cdot \mathrm{mL}^{-1}\right), 2$ ) noninoculated (non-AMF) athigh $\mathrm{P}\left(44 \mu \mathrm{g} \cdot \mathrm{mL}^{-1}\right), 3$ ) mixedAMF inoculum isolated form a corn field (sierra-maize) at low $\mathrm{P}, 4)$ mixed AMF inoculum isolated from a potato field (sierra-papa) at low P, 5) pure isolate of Glomus intraradicies (Schenck and Smith) at low P, 6) sierra-maize mixed AMF inoculum + formononetin, at low $\mathrm{P}$, and 7) sierra-papa mixed AMF inoculum + formononetin at low $\mathrm{P}$.

Selected indigenous Peruvian AMF isolates were collected from the highlands of Oyolo, Departamento de Ayacucho, Peru. Mixed inoculum containing Acaulospora spp., Glomus spp., Scutellospora spp., Gigaspora spp. and Sclerocystis spp. was harvested from 1) a sierra-maize (corn) production site at 3300 meters [sandy clay soil with textural analysis of $46 \%$ sand, $28 \%$ clay and $26 \%$ silt; the soil had $1.9 \%$ organic matter, an EC of $0.24 \mathrm{dS} \cdot \mathrm{m}^{-1}$, pH 5.9, 0.33\% $\mathrm{CaCO}_{3}, 1.2 \% \mathrm{MO}, 3.3 \mu \mathrm{g} \cdot \mathrm{g}^{-1}$ $\left.\mathrm{P}, 600 \mathrm{~kg} \cdot \mathrm{ha}^{-1} \mathrm{~K}_{2} \mathrm{O}\right]$; and 2) a sierra-papa (potato) production site at $3600 \mathrm{~m}$ [sandy loam soil with textural analysis of $59 \%$ sand, $16 \%$ clay and $25 \%$ silt; the soil had $2.6 \%$ organic matter, an EC of $0.35 \mathrm{dS} \cdot \mathrm{m}^{-1}, \mathrm{pH} 6.6,0.33 \%$ $\mathrm{CaCO}_{3}, 1.2 \% \mathrm{MO}, 26.6 \mu \mathrm{g} \cdot \mathrm{g}^{-1} \mathrm{P}, 2242 \mathrm{~kg} / \mathrm{ha}$ $\left.\mathrm{K}_{2} \mathrm{O}\right]$. These AMF were multiplied in a trap culture of Italian rye grass (Lolium perenne L.) and onion for four months. About $400 \mathrm{~g}$ of soil containing 2800 spores [7 spores/g] (sierra-maize AMF isolate) or 5600 spores [14 spores/g] (sierra-papa mixed AMF isolate), plus vegetative mycelium and roots of the trap culture plants were applied as a band at the bottom third of the pot, then covered with soil, and the roots of the potato tuber were allowed to grow into the band and become colonized. About $21.5 \mathrm{~g}$. of commercial inoculum of Glomus intraradices (Reforestation Tech International, Salinas, Calif.) containing 3000 to 5400 spores [most probable number (MPN)] was also banded. To reestablish background microflora, $100 \mathrm{~mL}$ of filtrate of the three inocula were screened through a $45-\mu \mathrm{m}$ sieve and Whatman filter paper \#4 and added back to the soil of noncolonized plants. Half of the Peruvian mixed isolates also received two 250-mL soil drench applications containing 15 $\mathrm{mg} \cdot \mathrm{L}^{-1}$ Myconate (VAMTech L.L.C., Lansing, Mich.), which is a water-soluble form of the flavonoid, formononetin. The drenches were applied at 3 and 4 weeks after emergence of shoots.

The experiment was initiated on 17 Sept. 1999 and terminated on 17 Dec. 1999. Average shade house minimum/maximum temperature ranged from $13.6 / 28.8^{\circ} \mathrm{C}$, and the maximum mean irradiance was $822.2 \mu \mathrm{mol} \cdot \mathrm{m}^{-2} \cdot \mathrm{s}^{-1}$.

Assessment of plant growth and development and leaf tissue elemental analysis. Final growth measurements of 15 plants per treatment $(n=15)$ were taken at day 90 after transplanting, and included leaf, shoot, root, stolon, tuber and total plant dry matter, tuber number, root to shoot ratio $\left(\mathrm{g} \cdot \mathrm{g}^{-1}\right)$, leaf to tuber ratio, $\left(\mathrm{g} \cdot \mathrm{g}^{-1}\right)$, phosphorus use efficiency $[\{\mathrm{PUE}\}$ (g tuber) $/(\mathrm{g} \mathrm{P} / \mathrm{kg})]$. Leaf area was based on a regression of leaf dry matter and area. The mycorrhizal inoculation effect (MIE) was determined by MIE $(\%)=($ dry matter of inoculated plant - dry matter of noninoculated plant $) \times 100 \times($ dry matter noninoculated/ plant $)^{-1}$ (Bagyaraj et al., 1988).

Leaf elemental analysis was done with an inductively coupled atomic emission spectrophotometer (3510 ICP; J.R Peters Laboratory, Allentown, Pa.). From fifteen plants per treatment, newly matured leaves from 5 plants were pooled into a single sample for analysis $(\mathrm{n}=3)$.

Assessment of mycorrhizal development. Soil aggregation, as a measure for extraradical hyphae development, was assessed by allowing the soil of five potted plants from each treatment to dry at room temperature $\left(25^{\circ} \mathrm{C}\right)$, screening the root system, and shaking it gently in order to obtain pieces of soil attached to roots and bound by fungal hyphae (Graham et al., 1982, Kough and Linderman, 1986). The attached soil was then removed by washing the roots, collecting the remnant soil and drying it in a forced air oven. The soil dry weight divided by root dry weight was utilized to calculate the extraradical hyphae index (ERH index).

For spore counts, samples consisting of 100 $\mathrm{g}$ of soil from five plants per treatment $(n=5)$ were processed through glycerol floatation and spore extraction methods (Furlan and Fortin, 1975; Schenck, 1982). The supernatant was resuspended in $20 \mathrm{~mL}$ of distilled water and three replicates of $1.0 \mathrm{~mL}$ were taken in order to perform spore counts. The results were recorded as number of spores per $\mathrm{g}$ soil.

For AMF analysis of roots, $1-\mathrm{cm}$ root segments from 15 plants per treatment were sampled at harvest and pooled to assess colonization percentage through clearing and staining of the root samples (Phillips and Hyman, 1970). Ten 1-cm stained root pieces were placed on each slide and three microscopic observations per $1-\mathrm{cm}$ root piece at $40 \times$ was made at the top, the middle and the bottom of each root piece. There were 15 slides per treatment $(n=450$ per treatment). The presence of arbuscules, vesicles and/or hyphae were recorded as total root colonization.

Statistical design. The experiment was composed of seven treatments in a completely randomized design. There was one prenuclear minituber per pot with each pot as a single replication. All data were analyzed using Analysis of Variance (ANOVA) (SAS Institute Inc., 2000).

\section{Results}

Plant growth and development. Non-AMF plants at low $\mathrm{P}$ had poorest growth, while non-AMF high $P$ plants had among the greatest overall growth in terms of leaf area, leaf, shoot, tuber and total plant dry matter, and tuber number (Table 1). High $\mathrm{P}$, non-AMF plants also had among the lowest leaf to tuber ratio, indicating greater efficiency in producing tuber mass, while low $\mathrm{P}$, non-AMF plants had the lowest efficiency (Table 1). All AMF plants had greater growth, including a higher root to shoot ratio, and a greater

$P$ use efficiency (PUE) than non-AMF

Table 1. Effect of arbuscular mycorrhizal fungi (AMF) native to Peru, a pure isolate of Glomus intraradices, the flavonoid, formononetin and phosphorus on growth and development of 'Yungay' potatoes.

\begin{tabular}{|c|c|c|c|c|c|c|c|c|c|c|c|c|c|}
\hline $\begin{array}{l}\mathrm{AMF} \\
\text { treatment }\end{array}$ & $\begin{array}{c}\mathrm{P} \\
\left(\mu \mathrm{g} \cdot \mathrm{mL}^{-1}\right)\end{array}$ & $\begin{array}{l}\text { Leaf } \\
\text { area }^{z} \\
\left(\mathrm{~cm}^{2}\right)\end{array}$ & $\begin{array}{l}\text { Leaf } \\
\text { dry } \\
\text { matter } \\
(\mathrm{g})\end{array}$ & $\begin{array}{l}\text { Shoot } \\
\text { dry } \\
\text { matter } \\
(\mathrm{g})\end{array}$ & $\begin{array}{l}\text { Root } \\
\text { dry } \\
\text { matter } \\
(\mathrm{g})\end{array}$ & $\begin{array}{l}\text { Tuber } \\
\text { dry } \\
\text { matter } \\
(\mathrm{g})\end{array}$ & $\begin{array}{c}\text { Tuber } \\
\text { no. }\end{array}$ & $\begin{array}{l}\text { Solon } \\
\text { dry } \\
\text { matter } \\
(\mathrm{g})\end{array}$ & $\begin{array}{l}\text { Total } \\
\text { plant } \\
\text { dry } \\
\text { matter } \\
(\mathrm{g})\end{array}$ & $\begin{array}{l}\text { Root } \\
\text { to } \\
\text { shoot } \\
\text { ratio } \\
\left(\mathrm{g} \cdot \mathrm{g}^{-1}\right)\end{array}$ & $\begin{array}{l}\text { Leaf } \\
\text { to } \\
\text { tuber } \\
\text { ratio } \\
\left(\mathrm{g} \cdot \mathrm{g}^{-1}\right)\end{array}$ & $\begin{array}{c}\text { PUE }^{y} \\
(\mathrm{~g} / \mathrm{g} \mathrm{P} / \mathrm{kg})\end{array}$ & $\begin{array}{c}M E^{x} \\
(\%)\end{array}$ \\
\hline Control & 11 & $619 \pm 33^{w}$ & $2.9 \pm 0.2$ & $3.3 \pm 0.2$ & $1.8 \pm 0.1$ & $2.5 \pm 0.6$ & $2.9 \pm 0.6$ & 1.1 & $11.5 \pm 0.7$ & $0.55 \pm 0.03$ & $4.3 \pm 1.8$ & $1.0 \pm 0.3$ & --- \\
\hline Control & 44 & $952 \pm 59$ & $4.5 \pm 0.3$ & $4.8 \pm 0.2$ & $2.3 \pm 0.2$ & $7.0 \pm 0.7$ & $6.5 \pm 0.6$ & 1.2 & $19.8 \pm 0.7$ & $0.50 \pm 0.05$ & $0.8 \pm 0.1$ & $2.0 \pm 0.2$ & --- \\
\hline S-Maize & 11 & $842 \pm 43$ & $4.0 \pm 0.2$ & $4.3 \pm 0.1$ & $2.8 \pm 0.1$ & $4.1 \pm 0.6$ & $4.5 \pm 0.7$ & 1.6 & $16.6 \pm 0.6$ & $0.64 \pm 0.03$ & $1.6 \pm 0.4$ & $1.6 \pm 0.2$ & 44 \\
\hline S-Papa & 11 & $852 \pm 36$ & $4.0 \pm 0.2$ & $4.4 \pm 0.1$ & $2.8 \pm 0.2$ & $4.4 \pm 0.7$ & $4.6 \pm 0.5$ & 1.8 & $17.4 \pm 0.6$ & $0.62 \pm 0.03$ & $1.8 \pm 0.5$ & $1.7 \pm 0.3$ & 51 \\
\hline Glomus intraradices & 11 & $779 \pm 34$ & $3.7 \pm 0.2$ & $3.6 \pm 0.1$ & $2.7 \pm 0.1$ & $5.4 \pm 0.8$ & $5.1 \pm 0.5$ & 1.2 & $16.7 \pm 0.9$ & $0.76 \pm 0.03$ & $0.9 \pm 0.1$ & $1.9 \pm 0.3$ & 45 \\
\hline S-Maize+ formononetin & 11 & $783 \pm 49$ & $3.7 \pm 0.2$ & $4.3 \pm 0.1$ & $2.9 \pm 0.2$ & $5.3 \pm 0.8$ & $4.6 \pm 0.8$ & 1.6 & $17.8 \pm 0.5$ & $0.68 \pm 0.04$ & $1.2 \pm 0.4$ & $2.0 \pm 0.3$ & 55 \\
\hline S-Papa+formononetin & 11 & $750 \pm 35$ & $3.5 \pm 0.2$ & $4.2 \pm 0.1$ & $3.1 \pm 0.2$ & $5.6 \pm 0.9$ & $5.1 \pm 0.8$ & 1.6 & $18.0 \pm 0.7$ & $0.74 \pm 0.05$ & $1.1 \pm 0.2$ & $2.2 \pm 0.3$ & 57 \\
\hline Significance & & 0.0006 & 0.0001 & 0.0001 & 0.0001 & 0.0038 & 0.0165 & NS & 0.0001 & 0.0001 & 0.0179 & 0.0511 & \\
\hline
\end{tabular}

${ }^{2 \dagger}$ Leaf area based on a regression of leaf dry matter.

y Phosphorus use efficiency [ $\{\mathrm{PUE}\}$ (tuber $[\mathrm{g}]) /(\mathrm{g} \mathrm{P} / \mathrm{kg})]$.

${ }^{\mathrm{x}} \mathrm{MIE}(\%)=(\mathrm{dm}$ of AMF plant $-\mathrm{dm} 11 \mu \mathrm{g} \mathrm{P} /$ non-AMF plant $) \times 100 \times(\text { dry matter } 11 \mu \mathrm{g} \text { P/non-AMF plant })^{-1}$

${ }^{\mathrm{w}}$ Mean and $\pm \mathrm{SE}, \mathrm{n}=15$. 
Table 2. Effect of arbuscular mycorrhizal fungi (AMF) native to Peru, a pure isolate of Glomus intraradices, the flavonoid, formononetin, and phosphorus on leaf elemental content of 'Yungay' potatoes (Solanum tuberosum).

\begin{tabular}{|c|c|c|c|c|c|c|c|c|c|c|c|c|c|c|}
\hline $\begin{array}{l}\mathrm{AMF} \\
\text { treatment }\end{array}$ & $\begin{array}{c}\mathrm{P} \\
\left(\mu \mathrm{g} \cdot \mathrm{mL}^{-1}\right)\end{array}$ & $\begin{array}{c}\mathrm{N} \\
\left(\mathrm{g} \cdot \mathrm{kg}^{-1}\right)\end{array}$ & $\begin{array}{c}\mathrm{P} \\
\left(\mathrm{g} \cdot \mathrm{kg}^{-1}\right)\end{array}$ & $\begin{array}{c}\mathrm{K} \\
\left(\mathrm{g} \cdot \mathrm{kg}^{-1}\right)\end{array}$ & $\begin{array}{c}\mathrm{Ca} \\
\left(\mathrm{g} \cdot \mathrm{kg}^{-1}\right)\end{array}$ & $\begin{array}{c}\mathrm{Mg} \\
\left(\mathrm{g} \cdot \mathrm{kg}^{-1}\right)\end{array}$ & $\begin{array}{c}\mathrm{B} \\
\left(\mathrm{g} \cdot \mathrm{kg}^{-1}\right)\end{array}$ & $\begin{array}{c}\mathrm{Cu} \\
\left(\mu \mathrm{g} \cdot \mathrm{g}^{-1}\right)\end{array}$ & $\begin{array}{c}\mathrm{Fe} \\
\left(\mu \mathrm{g} \cdot \mathrm{g}^{-1}\right)\end{array}$ & $\begin{array}{c}\mathrm{Mn} \\
\left(\mu \mathrm{g} \cdot \mathrm{g}^{-1}\right)\end{array}$ & $\begin{array}{c}\text { Mo } \\
\left(\mu \mathrm{g} \cdot \mathrm{g}^{-1}\right)\end{array}$ & $\begin{array}{c}\mathrm{Zn} \\
\left(\mu \mathrm{g} \cdot \mathrm{g}^{-1}\right)\end{array}$ & $\begin{array}{c}\mathrm{Na} \\
\left(\mu \mathrm{g} \cdot \mathrm{g}^{-1}\right)\end{array}$ & $\begin{array}{c}\mathrm{Al} \\
\left(\mu \mathrm{g} \cdot \mathrm{g}^{-1}\right)\end{array}$ \\
\hline Control & 11 & 49.2 & $2.4 \pm 0.1^{z}$ & $42.8 \pm 2.3$ & 22.4 & $5.5 \pm 0.1$ & $88 \pm 5$ & 19 & $423 \pm 34$ & 226 & 3 & $83 \pm 1$ & $557 \pm 27$ & 561 \\
\hline Control & 44 & 51.5 & $3.6 \pm 0.2$ & $31.5 \pm 1.5$ & 21.4 & $6.7 \pm 0.3$ & $93 \pm 3$ & 20 & $564 \pm 54$ & 243 & 4 & $69 \pm 4$ & $696 \pm 60$ & 723 \\
\hline S-Maize & 11 & 49.3 & $2.7 \pm 0.1$ & $29.9 \pm 0.6$ & 22.2 & $6.5 \pm 0$ & $97 \pm 4$ & 25 & $644 \pm 74$ & 241 & 2 & $88 \pm 1$ & $607 \pm 7$ & 894 \\
\hline S-Papa & 11 & 49.4 & $2.7 \pm 0$ & $31.1 \pm 0.3$ & 22.1 & $6.7 \pm 0.2$ & $98 \pm 1$ & 20 & $595 \pm 25$ & 249 & 2 & $80 \pm 1$ & $544 \pm 28$ & 808 \\
\hline Glomus intraradices & 11 & 51.5 & $2.7 \pm 0$ & $35.0 \pm 0.8$ & 20.5 & $5.7 \pm 0.2$ & $108 \pm 4$ & 23 & $525 \pm 10$ & 250 & 3 & $80 \pm 3$ & $574 \pm 27$ & 702 \\
\hline S-Maize + formononetin & 11 & 51.2 & $2.8 \pm 0.1$ & $32.7 \pm 0.7$ & 21.0 & $6.6 \pm 0.1$ & $93 \pm 2$ & 21 & $505 \pm 14$ & 211 & 3 & $81 \pm 3$ & $498 \pm 18$ & 666 \\
\hline S-Papa + formononetin & 11 & 51.9 & $2.8 \pm 0.1$ & $32.2 \pm 0.3$ & 20.7 & $6.5 \pm 0.1$ & $93 \pm 2$ & 20 & $514 \pm 44$ & 236 & 2 & $80 \pm 2$ & $516 \pm 34$ & 680 \\
\hline Significance & & NS & 0.0001 & 0.0001 & NS & 0.0002 & 0.0112 & NS & 0.0494 & NS & NS & 0.0025 & 0.0136 & NS \\
\hline
\end{tabular}

${ }^{\mathrm{z}}$ Mean and standard error; leaves of five randomly sampled plants were pooled as one replication, $\mathrm{n}=3$.

plants at low P. The mycorrhizal inoculation effect(MIE) ranged from 44\% to 57\%. Root dry matter and the root to shoot ratio of AMF plants were also greater than high $\mathrm{P}$, non-AMF plants. The sierra-papaAMF mix + formononetin was one of the best AMF treatments, based on tuber dry matter, PUE and MIE. Low P, AMF plants colonized with the sierra-papa AMF mix + formononetin had similar tuber number and tuber dry matter, and leaf to tuber $\left(\mathrm{g} \cdot \mathrm{g}^{-1}\right)$ ratio compared to high $\mathrm{P}$, non-AMF plants.

Leaf tissue elemental analysis. High P, non-AMF plants had the highest leaf tissue $P$, $\mathrm{Na}$ and lowest $\mathrm{Zn}$ (Table 2). AMF plants had greater $\mathrm{P}, \mathrm{Mg}$, and $\mathrm{Fe}$, and lower $\mathrm{K}$ than low $\mathrm{P}$, non-AMF plants. No treatment differences occurred with $\mathrm{N}, \mathrm{Ca}, \mathrm{Cu}, \mathrm{Mn}, \mathrm{Mo}$, or Al.

Mycorrhizal development. Colonization was high among all AMF inoculated plants (70\% to $80 \%$ ) (Table 3). Formononetin enhanced extraradical hyphae formation of the sierra-maize and sierra-papa AMF mixes and increased sporulation of the sierra-maize AMF mix (Table 3). The number of spores recovered from the Glomus intraradicies treatment was lowest, but root colonization by this isolate was one of the highest.

\section{Discussion}

This study shows the benefit of mycorrhiza as biofertilizers on growth, tuber yield, nutrient uptake and PUE of 'Yungay' potatoes. In low input, sustainable agriculture systems of the Peruvian highlands, it is important to use native mycorrhiza. While some limited studies have been done with nonnative mycorrhiza in Peru (Calderón, 1994; Moreno, 1988), this is the first successful report, to our knowledge, where native mycorrhiza were used as biofertilizers to enhance growth and yield of the important potato cultivar 'Yungay'. There were differences in plant growth, nutrient uptake and PUE among the AMF isolates. Formononetin also enhanced the growth effectiveness of the two Peruvian mixed isolates.

Plant growth and development. All of the AMF isolates enhanced growth of 'Yungay'. Mycorrhiza are known to enhance productivity of potatoes (Graham et al., 1976). AMF can also increase leaf surface area and plant growth by increasing P supply (Koide, 1998). The mycorrhizal inoculation effect (MIE) ranged from $44 \%$ to $57 \%$, indicating that 'Yungay' was moderately to highly mycorrhizal dependent under P-limiting conditions (Bagyaraj et al., 1988).
One of the best AMF treatments was the sierra-papa mixed isolate + formononetin - based on total plant dry matter, tuber development, leaf to tuber ratio $\left(\mathrm{g} \cdot \mathrm{g}^{-1}\right)$ and phosphorus use efficiency [(PUE) $\{\mathrm{g}$ tuber/g $\mathrm{P} / \mathrm{kg}$ \}] . Nutrient use efficiency estimation is used to measure plant capacity for uptake and use of nutrients for biomass production (Errebhi, et al. 1998). In horticulture production this can be measured by total biomass or economic yield produced by unit of mineral ions absorbed. At low P $\left(11 \mu \mathrm{g} \cdot \mathrm{mL}^{-1}\right)$, the PUE was greater in all AMF plants compared to non-AMF plants.

At low fertility, AMF enhanced tuber development. There were no statistical differences in tuber number, leaf to tuber ratio $\left(\mathrm{g} \cdot \mathrm{g}^{-1}\right)$ and tuber dry matter between the high $\mathrm{P}$, non-AMF and low P, sierra-papa AMF mix + formononetin; the later had 2.2-fold greater tuber dry matter than low P, non-AMF plants.

Leaf tissue elemental analysis. The higher tissue $\mathrm{P}$ in AMF than low $\mathrm{P}$, non-AMF plants was in part due to the ability of AMF to provide $\mathrm{P}$ to the plant, when $\mathrm{P}$ is less mobile in the soil because of decreased soil moisture content or with limited $\mathrm{P}$ supply, as in this study. Sometime leaves are very conservative in their $\mathrm{P}$ concentration. When more $\mathrm{P}$ becomes available, they produce greater leaf area and thus maintain the same tissue concentration levels (Smith and Read, 1997). However, at low $\mathrm{P}$, all AMF plants had greater leaf area, leaf dry matter and leaf $\mathrm{P}$ than non-AMF plants.
There was also greater total plant acquisition of $\mathrm{P}$ since the biomass of the AMF colonized plants was greater than non-AMF plants. In a nonmycorrhizal study, P-enhanced growth of potato plants was attributed to earlier canopy growth, increased radiation interception and subsequent greater biomass production (Jenkins and Ali, 1999).

AMF enhancement of plant growth may also be attributed to increased uptake of Fe and $\mathrm{Mg}$. The higher uptake of selected nutrients may also be due to greater $P$ uptake of AMF plants, i.e., the influence of higher P uptake on subsequent greater uptake of Fe is documented (Jones et al., 1991). AMF plants had reduced $\mathrm{K}$. This is in part due to the dilution effect of AMF plants with a larger biomass (Johnson et al., 1980).

While all AMF 'Yungay' plants had extraradical hyphae development, the sierra-papa AMF mix had among the highest development. AMF increases $\mathrm{P}$ absorption for the most part by increasing the absorptive surface areas in contact with the soil solution (Koide, 1998). AMF hyphae are much longer than most root hairs, which allows them to explore pockets of soil that are unavailable to non-AMF roots. Extraradical hyphae can enhance plant water status (Davies etal., 1992 and 2002) and increase nutrient uptake in other crops (Bethlenfalvay and Linderman, 1992; Davies etal., 2000).AMF explore the soil volume in a manner analogous to increasing root density. Extraradical hyphae bridge gaps between the soil and roots as well as

Table 3. Effect of arbuscular mycorrhizal fungi (AMF) native to Peru, a pure isolate of Glomus intraradices, the flavonoid, formononetin, and phosphorus on vesicle and arbuscule formation, total colonization, extraradical hyphae development and soil AMF spore formation of 'Yungay' potatoes.

\begin{tabular}{|c|c|c|c|c|}
\hline \multirow[b]{2}{*}{$\begin{array}{l}\text { AMF } \\
\text { Treatment }\end{array}$} & \multirow[b]{2}{*}{$\begin{array}{c}\mathrm{P} \\
\left(\mu \mathrm{g} \cdot \mathrm{mL}^{-1}\right)\end{array}$} & \multicolumn{3}{|c|}{$\begin{array}{c}\text { Extraradical } \\
\text { hyphae } \\
\text { index }\end{array}$} \\
\hline & & $\begin{array}{c}\text { Total } \\
\text { colonization } \\
(\%)\end{array}$ & $\begin{array}{c}\text { Soil aggregate } \\
\text { dry matter/ } \\
\text { root } \\
\left(\mathrm{g} \cdot \mathrm{g}^{-1}\right)\end{array}$ & $\begin{array}{c}\text { Spores } \\
\text { recovered/ } \\
\text { g soil }\end{array}$ \\
\hline Control & 11 & $0 \pm 0^{z, y}$ & $24.9 \pm 6.5^{z, x}$ & $3.9 \pm 0.4^{\mathrm{z}, \mathrm{w}}$ \\
\hline Control & 44 & $0 \pm 0$ & $27.1 \pm 2.1$ & $6.1 \pm 0.4$ \\
\hline S-Maize & 11 & $71.3 \pm 4.7$ & $54.5 \pm 8.7$ & $18.7 \pm 1.9$ \\
\hline S-Papa & 11 & $73.3 \pm 4.2$ & $70.7 \pm 5.8$ & $18.1 \pm 2.4$ \\
\hline Glomus intraradicies & 11 & $79.9 \pm 4.5$ & $57.1 \pm 12.3$ & $4.9 \pm 0.7$ \\
\hline S-Maize+ formononetin & 11 & $70.1 \pm 3.9$ & $79.4 \pm 5.2$ & $25.4 \pm 2.3$ \\
\hline $\mathrm{S}$-Papa+ formononetin & 11 & $78.6 \pm 4.9$ & $81.2 \pm 4.9$ & $18.1 \pm 1.6$ \\
\hline Significance & & 0.0001 & 0.0001 & 0.0001 \\
\hline
\end{tabular}

${ }^{\mathrm{z}}$ Mean and standard error.

${ }^{\mathrm{y}} \mathrm{n}=150$.

${ }^{\mathrm{x}} \mathrm{n}=5$.

${ }^{\mathrm{w}}$ From five 100 -g soil samples per treatment, three subsamples of $1 \mathrm{~mL}$ from $20 \mathrm{~mL}$ of resuspended supernatant per $100 \mathrm{~g}$ sample $=15$ observations per treatment. 
binding soil particles to each other (water stable aggregates) and to roots. This can be beneficial for enhancing nutrient uptake and minimizing water loss with diurnal fluctuations in soil water and subsequent soil shrinkage and gaps in the soil-root interface and between soil particles (Wright and Upadhyaya, 1998).

$\mathrm{P}$ nutrition is considered by many to be central to mycorrhizal enhancement of plant growth and its subsequent application to low input sustainable agricultural systems (Bethlenfalvay and Linderman, 1992). Phosphorus use efficiency (PUE) can also be measured by net photosynthesis $(A)$ per tissue $\mathrm{P}$ concentration, since $A$ is a key growth parameter, and $\mathrm{P}$ deficiency is a limiting factor to crop productivity. [In our study, PUE was based on tuber (g) development per g P/kg leaf dry matter]. Higher PUE is associated with less leaf mass needed to generate tuber mass, which suggests greater leaf and photosynthetic efficiency in AMF plants. The PUE of AMF treatments (all at low $\mathrm{P}$ ) was similar to the high $\mathrm{P}$, non-AMF plants - even though the later were given 4-fold greater P supply. In a study with $G$. intraradices (Aguilera-Gomez et al., 1999), highest PUE ( $A$ /P) occurred with AMF chile ancho plants at the lowest Plevel, whereas PUE was higher in nonAMF plants at moderate and high P. High PUE has been reported in mycorrhizal plants (Brown and Bethlenfalvay, 1988; Davies et al., 1993). Plants with optimum P concentration should be more vigorous with higher photosynthetic rates and stomatal conductance than plants with limiting P (Dietz and Foyer, 1986; Hensen et al., 1998). In a greenhouse, container study, formononetin stimulated greater extraradical hyphae development, net photosynthesis, stomatal conductance and shoot development in Russet Norkotah potatoes (Davies et al., 1999).

Mycorrhizal development. Potato plants are not known for high colonization levels, even though trace levels $(0.4 \%$ colonization) are reported to enhance growth (Niemira, et al., 1995). With 'Yungay', high colonization levels from $70 \%$ to $80 \%$ occurred. Part of this may be the high initial inoculum levels utilized and the particular isolates selected. While it was beyond the scope of the current study to establish a minimum inoculation level for AFM effectivity, future studies should be conducted to determine economic levels of AMF inoculation. Formononetin enhanced extraradical hyphae formation of the sierrapapa AMF mix, but did not affect total root colonization. AMF colonization enhances soil aggregation through extraradical hyphae that are external to plant roots and by exuding the glycoprotein, glomalin, from extraradical hyphae that cements soil microaggregates into larger soil aggregate structures (Wright and Upadhyaya, 1998). The improved soil tilth that occurs enhances air and water percolation, and improves root system access to soil water and nutrients.

In a study with AMF maize, formononetin enhanced total root colonization from low to high soil P conditions (Fries et al., 1998). Phosphatases are secreted into the soil by roots and likely influenced by soil P status and
AMF colonization. Acid phosphatase (ACP) and alkaline phosphatase (ALP) were closely related to root colonization. Soil $\mathrm{P}$ affects enzymes such as ACP, which are involved in the increase uptake of $\mathrm{P}$ from soil, while ALP has been linked to active phosphate assimilation and transport in roots (Fries et al., 1998).

All AMF spores, young and old, were counted in this study. Soil spore number is a function of AMF species, climate, soil characteristics, seasonality, etc. In another study conducted in a farmer's field at $3900 \mathrm{~m}$ in the Peruvian Highlands, the rhizosphere soil of control plants contained $6.3 \pm 1.2$ spores $/ g$ of soil (the land had been fallow for 5 years), whereas formononetin treatments had 19.4 \pm 1.1 spores/g of soil (Davies et al., 2002). At higher altitudes in the Andean highlands, temperature is much lower, and sporulation of mycorrhiza and plant growth are reduced. There is only limited information on mycorrhizal species and soil spore levels in selected production sites in Peru (Calderon, 1994). Soil spore numbers have been reported from 50 to 800 spores/g soil (Nemec, 1974). In another study Sutton and Barron (1972) reported from 20 to 92 spores/g soil, and others researchers have reported from 0.1 to 37 spores/g soil (Hayman et al., 1975; Smith and Read, 1997). In the current containerized study, inoculated plants of 'Yungay' had from 5 to 25 spores/g soil. While formononetin enhanced spore number of the sierra-maize AMF mix, it did not affect sporulation of the sierra-papa mixed isolate. Both AMF mixed isolates contained Acaulospora spp., Glomus spp., Scutellospora spp., Gigaspora spp., and Sclerocystis spp. The low spore number of Glomus intraradicies was due to its sporulation characteristics. The $G$. intraradicies was used in comparison with the Peruvian isolates since it is a very aggressive isolate (Davies et al., 1999).

In subsistence agricultural systems, it is important to use indigenous AMF that are ecotypically adapted to the site. One of the strengths of this paper is that it shows potential benefits of applying formononetin or other effective flavonoids to stimulate the effectivity of native, ecotypically adapted mycorrhiza. Formononetin used in combination with indigenous isolates, could also allow for a lower, more cost-effective levels of AMF inocula to be utilized. The cost of formononetin would need to be considerably less than P-based fertilizers, which are estimated at $\$ 330$ to $\$ 460$ per hectare (J.C. Miller, Jr., personal communication). Formononetin has been reported to enhance effectivity of mycorrhizal plants (Koide et al., 1999; Nair et al., 1997). Hence, there are excellent opportunities to use and manipulate AMF to enhance crop productivity and reduce agricultural chemical inputs.

In summary, AMF enhancement was in part due to greater $\mathrm{P}, \mathrm{Fe}$, and $\mathrm{Mg}$ uptake, a higher PUE, and greater extraradical hyphae formation. One of the best AMF treatments was the Sierra-Papa AMF mix + formononetin based on tuber and total plant dry matter, mycorrhizal enhancement effect and PUE.

Beneficial AMF are one of the important cornerstones of sustainable agricultural sys- tems. They can make plants more efficient in using available soil water and fertility; i.e., they serve as biofertilizers and increase drought resistance and plant productivity. A long-term goal of our research is to use formononetin in stimulating native populations of mycorrhiza to enhance potato crop productivity.

\section{Literature Cited}

Aguilera-Gomez, L., F.T. Davies, Jr., V. OlaldePortugal, S.A. Duray, and L. Phavaphutanon. 1999. Influence of phosphorus stress and endomycorrhiza on gas exchange, plant growth and mycorrhizal development of chile ancho pepper (Capsicum annuum L. cv. San Luis). Photosynthet. 36:441-449.

Bagyaraj, F.J., A. Manjunath, and Y.S. Govinda. 1988. Mycorrhizal inoculation effect on different crops. J. Soil Biol. Ecol. 8:98-103.

Bethlenfalvay, G.J. and R.G. Linderman (eds.). 1992. Mycorrhizae in sustainable agriculture. Amer. Soc. Agron. Publ. 54.

Black, R.L.B. and P.B. Tinker. 1977. Interaction between the effects of vesicular-arbuscular mycorrhizae and fertilizer phosphorus on yields of potatoes in the field. Nature (London) 267:510-511.

Brown, M.S. and G.J. Bethlenfalvay. 1988. The Glycine-Glomus-Rhizobium symbiosis. VII. Photosynthetic nutrient use efficiency in nodulated, mycorrhizal soybeans. Plant Physiol. 86:1292-1297.

Calderón, M.C. 1994. Ocurrencia natural de la micorriza vesicular en algunos cultivos y lugares del Peru. Revista Anales Cientifico UNALM 43(1).

Davies, Jr., F.T., C. Calderón, and Z. Huaman. 2002. Influence of a flavonoid (formononetin) on mycorrhizal activity and potato crop productivity in the altiplano of Peru, p. 285-286 (abstr.) Proc. 26th Intl. Hort. Congr., Toronto, Ontario, Canada. 11-17 Aug. 2002.

Davies, Jr., F.T., V. Olalde-Portugal, H.M. Escamilla, R.C. Ferrera-Cerrato, M.J. Alvarado, and J. Espinosa. 2000. Alleviating phosphorus stress of chile ancho pepper (Capsicum annuum L. cv. San Luis) by arbuscular mycorrhizal inoculation. J. Hort. Sci. Biotechnol. 75:655-661.

Davies, Jr., F.T., V. Olalde-Portugal, L. AguileraGomez,M.J.Alvarado, R.C. Ferrera-Cerrato, and T.W. Boutton. 2002. Alleviation of drought stress of chile ancho pepper (Capsicum annuum L. cv. San Luis) with arbuscular mycorrhiza indigenous to Mexico. Scient. Hort. 92:347-359.

Davies, Jr., F.T., J.R. Potter, and R.G. Linderman. 1992. Mycorrhiza and repeated drought exposure affect drought resistance and extraradical hyphae development of pepper plants independent of plant size and nutrient content. J. Plant Physiol. 139:289-294.

Davies, Jr., F.T., J.R. Potter, and R.G. Linderman, R.G. 1993. Drought resistance of mycorrhizal pepper plants independent of leaf $P$ concentration-response in gas exchange and water relations. Physiol. Plant. 87:45-53.

Davies, Jr., F.T., S.E. Svenson, J.C. Cole, L. Phavaphutanon, S.A. Duray, V. Olalde-Portugal, C.E. Meier, and S.H. Bo. 1996. Non-nutritional stress acclimation of mycorrhizal woody plants exposed to drought. Tree Physiol.16:985-993.

Davies, Jr., F.T., J.N. Egilla, J.C. Miller, Jr., and J.A. Saraiva Grossi. 1999. Influence of mycorrhiza and an isoflavonoid on plant growth and gas exchange of potatoes started from minitubers. HortScience 34(3):498.

Devaux, A., J. Vallejos, R. Hijmans, and J. Ramos. 1997. Respuesta agonómica de dos variedades 
de papa (spp. Tuberosum y andigena) a deferentes niveles de fertilización mineral. Revista Latinoamericana de la Papa 9/10(1).

Dietz, K.J. and C. Foyer. 1986. The relationship between phosphate status and photosynthesis in leaves-Reversibility of the effects of phosphate deficiency on photosynthesis. Planta. 167:376-381.

Errebhi, M., C.J., Rosen, F.I. Lauer, M.W. Martin, J.B. Bamberg, and D.E. Birong. 1998. Screening of exotic potato germplasm for nitrogen uptake and biomass production. Amer. J. Potato Res. 75:93-100.

Fries, L.L.M, R.S. Pacovsky, G.R. Safir, and J. Kaminski. 1998. Phosphorus effect on phosphatase activity in endomycorrhizal maize. Physiol. Plant. 103:162-171.

Furlan, V. and J.A. Fortin. 1975.Aflotation-bubbling system for collecting Endogonaceae spores from sieved soil. Naturaliste Can. 102:663-667.

Graham, S.O, N.E. Green, and J.W. Hendrix. 1976. The influence of vesicular-arbuscular mycorrhizae on growth and tuberization of potatoes. Mycologia. 68:925-929.

Graham, J.H., R.G. Linderman, and J.A. Menge. 1982. Development of external hyphae by different isolates of mycorrhizal Glomus spp in relation to root colonization and growth of Troyer citrange. New Phytol. 91:183-189.

Hensen, C.W., J. Lynch, and C.O. Ottosen. 1998. Response to phosphorus availability during vegetative and reproductive growth of chrysanthemum: I. Whole-plant carbon dioxide exchange. J. Amer. Soc. Hort. Sci. 123:215-222.

Hayman, D.S., A.M. Johnson, and I. Ruddlesdin. 1975. The influence of phosphate and crop species on Endogone spores and vesiculararbuscular mycorrhiza under field conditions. Plant Soil. 43:589-495.

Hewitt, E.J. 1966. Sand and water culture methods in the study of plant nutrition. In: Technical communication No 22. 2nd ed. Rev. Commonwealth Agr. Bur., London.

Jenkins, P.D. and H. Ali. 1999. Growth of potato cultivars in response to application of phosphate fertilizer. Ann. Appl. Biol. 135:431-438.

Johnson, C.R., J.N. Joiner, and C.E. Crews. 1980. Effects of N, K, and Mg on growth and leaf nutri- ent composition of three container grown woody ornamentals inoculated with mycorrhizae. J. Amer. Soc. Hort. Sci. 105:286-288.

Jones, J.B., B. Wolf, and H.A. Mills. 1991. Plant analysis handbook. Micro-Macro Publ., Athens, Ga.

Kough, J.L. and R.G. Linderman. 1986. Monitoring extra-matrical hyphae of a vesicular-arbuscular mycorrhizal fungi with an inmunofluorescence assay and the soil aggregation technique. Soil Biol. Biochem. 18:309-313.

Koide, R.T. 1998. Ecological considerations of mycorrhizal symbiosis. In: J.P. Lynch and J. Deikman (eds.). Phosphorus in plant biology: regulating roles in molecular, cellular, organismic and ecosystem processes. Amer. Soc. Plant Physiol., Rockville, Md.

Koide, R.T., L.L. Landherr, Y.L. Besmer, J.M. Detweiler, and E.J. Holcomb. 1999. Strategies for mycorrhizal inoculation of six annual bedding plant species. HortScience 34:1217-1220.

Lauer, M.J., S.G. Pallardy, D.G. Blevins, and D.G. Randall. 1989. Whole leaf carbon exchange characteristics of phosphate deficient soybean (Glycine max L.). Plant Physiol. 91:848-854.

Linderman, R.G. 1994. Role of VAM fungi in biocontrol. In: F.L. Pfleger and R.G. Linderman (eds). Mycorrhizae and plant health. Amer. Phytophathol. Soc. Press, St. Paul, Minn.

Maynard, D.N and G.J. Hochmuth 1997. Knott's handbook for vegetable growers. 4th ed. John Wiley \& Sons, New York.

Mcarther, D.A.J and N.R. Knowles. 1993. Influence of species of vesicular-arbuscular mycorrhizal fungi and phosphorus nutrition on growth, development and mineral nutrition of potato (Solanum tuberosum L.). Plant Physiol. 102:771-782.

Moreno, P. 1988. Micorrizas en papa (Solanum tuberosum) repuesta en el crecimiento y nutricion de plantas inoculadas en invernadero y en campo. Revista Latinomericana de la Papa 1:84-99.

Nair, M.G., G.R. Safir, R.E. Schutzki, and B.A. Niemira. 1997. Alkai metal formononetin and method of mycorrhizal stimulation. U.S. Patent \#5691275; 25 Nov. 1997.

Nemec, S. 1974. Population of the Endogone in strawberry fields in relation to root rot infection. Trans. Brit. Mycol. Soc. 62:45-49.
Niemira, B.A., G.R. Safir, R. Hammerschmidt, and G.W. Bird. 1995. Production of prenuclear minitubers of potato with peat-based arbuscular mycorrhizal fungal inoculum. Agron. J. 87:942-946.

Niemira, B.A., R. Hammerschmidt, and G.R. Safir. 1996. Postharvest suppression of potato dry rot (Fusarium sambucinum in prenuclear minitubers by arbuscular mycorrhizal fungal inoculum. Amer. Potato J. 87:509-515.

Pfleger, F.L. and R.G. Linderman (eds.). 1994. Mycorrhizae and plant health. Amer. Phytophathol. Soc. Press, St. Paul, Minn.

Phillips, J.M. and D.S. Hyman. 1970. Improved procedures for clearing and staining parasitic and vesicular-arbuscular mycorrhizal fungi for rapid assessment of infection. Trans. Brit. Mycololo. Soc. 55:158-161.

SAS Institute Inc. 2000. SAS/stats user's guide. version 8. SAS Inst. Inc, Cary, N.C.

Schenck, N.C. (ed.). 1982. Methods and principles of mycorrhizal research. Amer. Phytopathol. Soc., St. Paul, Minn.

Sieczka, J.B. and R.E. Thornton (eds.). 1993. Commercial potato production in North America: Potato Association of America handbook. Potato Assn. Amer., Orono, Maine.

Sieverding, E. 1991. Vesicular-arbuscular mycorrhiza management in tropical agrosystems. (Deutsche Gesellschaft für Technische Zusammenarbeit). Eschborn, Germany.

Smith, S.E. and D.M. Read. 1997. Mycorrhizal symbiosis. 2nd ed. Academic Press, London, U.K..

Sutton, J.C. and G.L. Barron. 1972. Population dynamics of Endogone spores in soil. Can. J. Bot. 50:1909-1914.

Thomson, B. D., A.D. Robson, and L.K. Abott. 1991. Soil mediated effects of phosphorus supply on the formation of mycorrhizas by Scutellispora calospora (Nicol \& Gerd.) Walker and Sanders on subterranean clover. New Phytol. 118:463-469.

Wright, S.F. and A. Upadhyaya. 1998. A survey of soils for aggregate stability and glomalin, a glycoprotein produced by haphae of arbuscular mycorrhizal fungi. Plant Soil 198:97-107. 